\title{
Airborne Contamination Control through Directed Airflow in the Exam Room: A Pilot Study Using a Membrane Diffuser
}

\author{
Debajyoti Pati $^{1 *}$, Michael P. Pietrzak ${ }^{1}$, David Duthu ${ }^{2}$, Ting-Kwo George Lei ${ }^{3}$, \\ David Vincent $^{1}$, Tom Franklin ${ }^{2}$, Thomas E. Harvey, Jr. ${ }^{1}$, and Troy Ransdell ${ }^{1}$ \\ ${ }^{1}$ HKS Architects, 1919 McKinney Avenue, Dallas, TX \\ ${ }^{2}$ CCRD Partners, 808 Travis Street Suite 200, Houston, TX \\ ${ }^{3}$ Fluid Dynamics Solutions, Inc., 12453 S.E. Mountain Sun Lane, Clackamas, OR, USA
}

\begin{abstract}
Airborne infections have been documented as a major source of hospital acquired infection - one of the major concerns in healthcare delivery. An important factor contributing to airborne infection is cross contamination through air particulate dispersion as affected by the ventilation system design. Clean room technology (with membrane ceiling) has been successfully used in technology and pharmaceutical industries to control airborne contamination. This study examined the performance of membrane ceiling technology in controlling air particulate dispersion in a mock-up exam room. It included both performance tests in a mock-up room and a simulation study of six different ventilation system designs using Computational Fluid Dynamics (CFD) analysis. Findings suggest that a membrane diffuser directed airflow ventilation strategy occupying approximately $20 \%$ to $30 \%$ of the ceiling surface and placed over the patient in a contemporary sized exam room provides a less turbulent airflow pattern and less mixing of the air between the patient and others in the room.
\end{abstract}

Keywords: membrane ceiling, HVAC system, emergency department, infection control

\section{INTRODUCTION}

Among the most concerning issues of healthcare is the transmission of infections in healthcare facilities. The Institute of Medicine reports that preventable adverse patient events, including hospital-acquired infections, are responsible for 44,000-98,000 deaths annually at a cost of $\$ 17-\$ 29$ billion [1]. It is uncertain as to the number of infections that are acquired as a result of contact with contaminated equipment, hands or other materials as opposed to airborne acquisition of the infectious agents. Nevertheless, a substantial body of literature has documented the threat posed by airborne infection in healthcare settings, and the role of Heating Ventilation and Air Conditioning (HVAC) system design in infection control [2-19]. A key factor affecting airborne infection is cross contamination through air particulate dispersion determined by the HVAC system design. Airborne contamination can occur in a number of ways including aerosolizing

*Corresponding author: dpati@hksinc.com 
from human respiration/cough, ventilation system transmission, or simply turbulence that stirs up particulate matter in the room.

Critical care (care involving high-acuity patients) in hospitals is typically provided in intensive care units (ICU), emergency departments (ED), and procedure spaces supporting critical care such as operating rooms (OR). Among the settings involving critical care delivery, airborne contamination control in the emergency department constitutes a significant challenge. That is because patients in EDs are not prescreened for infectious diseases, and share the same physical enclosure and ventilation system, except for a few types of patients with known diseases.

While a large number of clinical outcome studies are not available on the topic of airborne infection in the emergency department, existing literatures underscore the challenge associated with controlling cross-contamination. The study by Moran et al. [20] on tuberculosis patients, for instance, underscores the clinical challenge in timely identification and isolation of contagious patients in the ED. A similar finding of Monmany et al [21] shows challenges in detection during influenza epidemics. The awareness has further increased with the advent of novel forms of pandemic over the past decade. Li and Gu [22] present a case involving SARS and how ED attributes contributed to staff infections. Pandemics like SARS and H1N1 have prompted discussions in professional literature related to ED design for controlling airborne contamination, for instance, Huddy's [23] article in response to the H1N1 pandemic. Thus, control of airborne contaminants is as important in EDs as in other critical care settings, such as burn units. A specific area of concern in ED is the exam room. An ED exam room is a space where one to three hospital staff can physically examine a patient in close quarters, collect information, and discuss personal matters in privacy.

Control of dispersion of airborne particulates could provide a novel strategy to examining and controlling airborne infection transmission in healthcare settings. Membrane ceiling has been commonly and successfully used in clean rooms in the technology and pharmaceutical sectors, and offers a potential strategy to control airborne contamination in healthcare facilities.

Normally, ventilation requires perforation either in the ceilings, walls or floors for air supply and return. The use of "clean room" ceiling membranes allows for large airflows in a laminar or unidirectional fashion with minimal pressure drop or noise development. The percentage of the ceiling that is dedicated to the membrane in an exam room is dependent upon the desired flow characteristics and code limitations. The membrane material needs to be cleanable as well as being able to withstanding decontamination with hydrogen peroxide or other chemical solutions. The membrane ceiling should allow light and air to pass through.

From an interior design standpoint, the placement of numerous lights behind the membrane can allow a uniform light source in the room eliminating shadows. It also eliminates perforations in the ceiling for light fixtures. Lights can be changed through the interstitial space or by removal of the membrane frame. The membrane itself may be colored or dyed to meet interior design requirements. The membrane will be directly fused to hard surface on the edges. The size of the membrane in relation to the room ultimately is driven by safety limitations that require fire suppression coverage and other elements in the ceiling. 
A hospital room ventilation system ideally should be designed to reduce the spread of contamination not only from the ventilation system itself, but also to provide airflow patterns to reduce cross contamination between persons in a room. An ideal system would divert particles from breathing or coughing harmlessly away from another individual in a room. Clearly, with extreme close contact the ventilation system could not overcome the force of a cough and provide protection in all circumstances. However, a system with relatively predictable flow characteristics could mitigate the transmission of infectious particles in the clinical environment. Downdraft or vertical laminar flow air movement has been shown to be effective in clean rooms, bacteriological laboratories and other applications where contamination risks are high [24]. This type of downdraft system might be applied in the standard ED examination room or hospital inpatient sleeping room to potentially reduce cross contamination. A full laminar flow system with the high velocities required by clean rooms applied to all rooms in the hospital would incur a significant cost associated with conditioning a large volume of air. However, a membrane diffuser that covers a significant area over the patient and that provides directed airflow might provide advantages in terms of predictable particle flows, lower diffuser noise, less pressure drop and lower velocities of flow with the same air exchanges per hour. These advantages could potentially translate into reduced cross contamination and more patient comfort (less draft and less noise) as well as reduced energy requirements (assuming less delivery pressure required).

A review of the literature found a study using computational fluid dynamics (CFD) analysis and mock-up room with air flow tests to analyze air flow and determine better diffuser arrangements in a typical burn unit room [25]. It showed that the configuration, placement and sizing of the diffusers had an impact on particle flow and probably on infection control of burn patients. However, grille type diffusers were used as opposed to the membrane diffuser. Therefore, we have undertaken the present pilot study following the same methods (CFD analysis and mock-up room with air flow tests) to evaluate and compare air flow characteristics of a standard ventilation system and a membrane-diffuser-directed flow strategy.

\section{METHODS}

\subsection{Research Design}

A multi-method approach was taken in the study, including performance tests in a mock-up room and simulation study using CFD analysis. The study involved six key steps:

1. Development of a room design for the study.

2. Identification of an appropriate material for membrane ceiling.

3. Video recording of smoke test in the mock-up room.

4. Development of a base model in CFD and validation of the model using data from the mock-up tests.

5. Simulation of six ventilation design configurations to examine air particulate dispersion patterns, and Mass Fraction (mf) Profile at $7.62 \mathrm{~cm}(3 ")$ above patient.

6. Comparative assessment of the six simulation models. 


\subsection{Methodology Justification}

It was decided to conduct both a CFD analysis and track directional airflow and entrainment capability of air return in an actual size room mock up study with preliminary smoke tests to analyze particle dispersion, since the literature shows that smoke testing alone does not provide for accurate test data [26].

\subsection{The Exam Room Mock Ups}

A full-size mock up of a contemporary ED examination room was constructed to simulate the actual size and patient bed layout. This mock up examination room was $3.66 \mathrm{~m}\left(12^{\prime}\right)$ in width, $4.88 \mathrm{~m}\left(16^{\prime}\right)$ in length and $2.74 \mathrm{~m}\left(9^{\prime}\right)$ in ceiling height. An entrance door was located similar to a typical exam room configuration. The dimensioned layout included a standard size patient bed placement, and associated utility head wall detail, as exhibited in Figure 1. The air distribution system for the mock-up room included a supply and return air system with similar temperature, air change rate and humidity control performance as a typical ED patient room HVAC system. The mock up air distribution system featured air change rate from 12 to 15 air changes per hour, providing approximately $12.18 \mathrm{~m}^{3} / \mathrm{min}(430 \mathrm{cfm})$ supply air volume flow rate on a sustained basis across the supply membrane diffuser area, temperature control of the supply air and return air system to gradient profile of $22.22^{\circ}$ to $24.44^{\circ} \mathrm{C}$, $\pm 1.11^{\circ} \mathrm{C},\left(72^{\circ}\right.$ to $\left.76^{\circ} \mathrm{F}, \pm 2^{\circ} \mathrm{F}\right)$, and air distribution velocity from 15.24 to $53.34 \mathrm{~m} / \mathrm{min}$ (50 to 175 feet per minute) depending on size adjustments made to the membrane diffusion area. Room relative humidity (RH) was maintained at 50\% during testing.

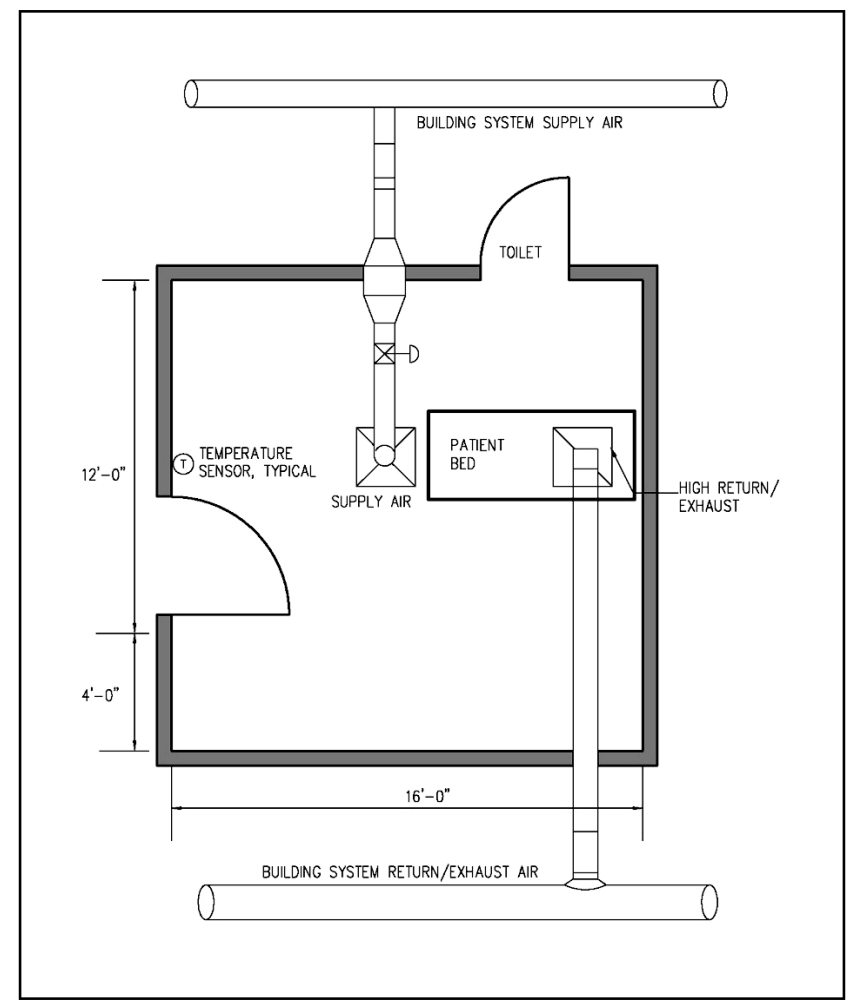

Figure 1. Layout of the mock-up examination room. 
With considerable empirical data already available in the literature to support traditional ceiling diffuser airflow patterns [27], the design team elected to construct the patient mock-up room utilizing the membrane diffuser panel system and not constructing traditional diffuser layouts. This allowed for data gathered for the membrane diffuser system to be tested against the published data for more traditional ceiling diffuser and return grille layout, as well as against that of documented CFD modeling from previous studies [27].

Two different ceiling membrane diffuser coverage areas were tested for the actual airflow. The first test configuration considered an area that provided an effective ceiling coverage of a $1.22 \mathrm{~m} \times 3.05 \mathrm{~m}=3.72 \mathrm{~m}^{2}\left(4^{\prime} \times 10^{\prime}=40 \mathrm{SF}\right)$ area located directly above the patient bed (Figure 2). The second test configuration was similar to the first except that the effective ceiling coverage was $1.83 \mathrm{~m} \times 3.05 \mathrm{~m}=5.57 \mathrm{~m}^{2}\left(6^{\prime} \times 10^{\prime}=60 \mathrm{SF}\right)$. The area surrounding the membrane diffuser panels on the perimeter of the room were blanked off to simulate a hard ceiling system providing for no airflow. Lighting was located within the ceiling plenum directly above the membrane diffuser fabric and not projecting into the room. Heat dissipation from the lighting fixtures was considered in the room internal heat gain and the supply air temperature of $12.78^{\circ} \mathrm{C}$ to $18.89^{\circ} \mathrm{C}\left(55^{\circ} \mathrm{F}\right.$ to $\left.66^{\circ} \mathrm{F}\right)$.

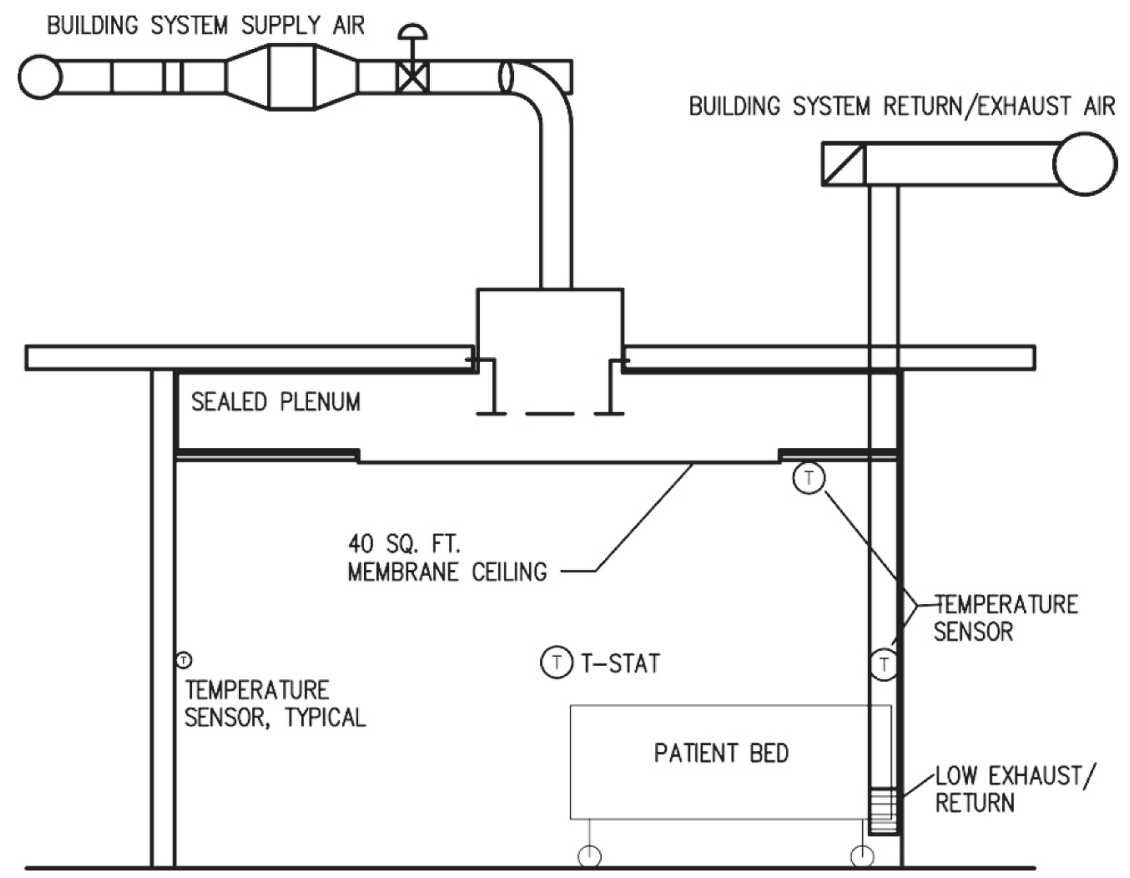

Figure 2. Sectional elevation of the mock-up examination room showing the positioning of the membrane diffuser. 
In each case, the return air collection points were located at the center of the patient bed head wall in a low wall configuration, starting approximately $35.56 \mathrm{~cm}$ to $60.96 \mathrm{~cm}$ (14" to 24") above the finished floor for a total return area coverage of $0.56 \mathrm{~m}^{2}$ (6 SF) and with a return air velocity of approximately $22.86 \mathrm{~m} / \mathrm{min}(75 \mathrm{ft} / \mathrm{min})$, centered in the room at the patient head wall. Other operating conditions factored into the exam room mockup included: a) discharge air velocity from the membrane ceiling was assumed uniform, b) sensible heat dissipated by each person was assumed constant over the duration of the tests, c) exam room doors were closed, and d) persons are in slow active motion during room testing.

The research team considered in the examination room mockup elements of room design that would closely match those recommended by the Guidelines for Design and Construction of Health Care Facilities [28], Planning, Design and Construction of Health Care Facilities [29], ASHRAE design recommendations for healthcare environments [30], and the design history and operating standards of the Washington Hospital Center (www.whcenter.org).

\subsection{Membrane Material Selection}

The membrane material selection did not include a full evaluation to determine which fabric is superior but was limited to simply determining a fabric that was suitable for a potential hospital application. Such fabrics are used in ceilings for clean rooms and some laboratory applications. The study group considered two commercial fabrics, and determined the suitability of the fabric based on the following: (a) flow characteristics, (b) life cycle, (c) easiness to clean, (d) resistance to degradation from $\mathrm{H}_{2} \mathrm{O}_{2}$ and UV (ultra violet) light, (e) fire resistance acceptable to hospital standards, and (f) cost and availability. The fabric chosen was a polypropylene monofilament fabric (with UV additives), primarily because of its easiness to be cleaned, resistance to UV degradation, class A fire rating, low pressure drop (1.14 mm W.G.; 0.045" W.G.) at an air flow rate of $27.43 \mathrm{~m} / \mathrm{min}$ to $33.53 \mathrm{~m} / \mathrm{min}$ (90 to $110 \mathrm{ft} / \mathrm{min}$ ), and its availability.

For the mock up tests, the membrane fabric was stretched over both sides of an anodized aluminum frame with epoxy-sealed edges. In this configuration, only one surface was exposed to the room. Only the room-facing fabric was subject to aseptic decontamination while the plenum side of the second fabric was protected from room exposure by the one-way movement of air across the fabric. Ability of the membrane to provide a controlled air direction was confirmed in the mock up tests. The membrane performance was based on a maximized use of filtered air, which was introduced into the space by diffusing the air evenly over an enlarged area. The mock up video test data confirmed that the membrane provided for an even distribution of air over the affected membrane ceiling plane thereby reducing the turbulent effects of air distribution. Turbulent effects hold particulates suspended in the negative pressure regions, and have a tendency to distribute air horizontally instead of directly downward in a laminar flow pattern. This horizontal airflow results from the medium to high velocity air movement generated by aspirating diffusers. 


\subsection{Computational Fluid Dynamics (CFD) Analysis}

As CFD analysis could provide information of the airflow field in greater detail, it was performed in this study to confirm, compare and extend the results observed in the mock up tests, particularly for various ventilation design concepts.

Six CFD models, as shown Figures 3 through 8, were developed based on the configuration of the examination room mock-up. These six CFD models represent six different scenarios - each has the same room configuration, internal heat gain and patient breathing rate, but differ in air supply and return extract setups. The goal of the analysis was to use the CFD data to understand airflow structures and compare ventilation performances among the six scenarios. The main input data for the six CFD models are outlined in Table 1 . All of the CFD models were based on the following assumptions:

1. The supply airflow is maintained at $12.18 \mathrm{~m}^{3} / \mathrm{min}(430 \mathrm{cfm})$ at $18.89^{\circ} \mathrm{C}\left(66^{\circ} \mathrm{F}\right)$.

2. The velocity at the membrane ceiling discharge surface is uniform.

3. Human sensible heat dissipation is at $92.26 \mathrm{~W} /$ person $(315 \mathrm{Btu} /(\mathrm{hr}-$ person $)$ ) for all models except for Model IV where human sensible heat dissipation is reduced to $64.43 \mathrm{~W} /$ person $(220 \mathrm{Btu} /(\mathrm{hr}-$ person $)$ ).

4. Examination room door is closed.

5. Examination room toilet door is closed.

6. The space is at steady state conditions with no motion of persons or objects.

7. There is no heat transfer from adjacent rooms/spaces/equipment.

8. The source of microbial contaminates is expiratory air from each person in the room, with a breathing rate of $6000 \mathrm{ml} / \mathrm{min}(0.21 \mathrm{cfm})$.

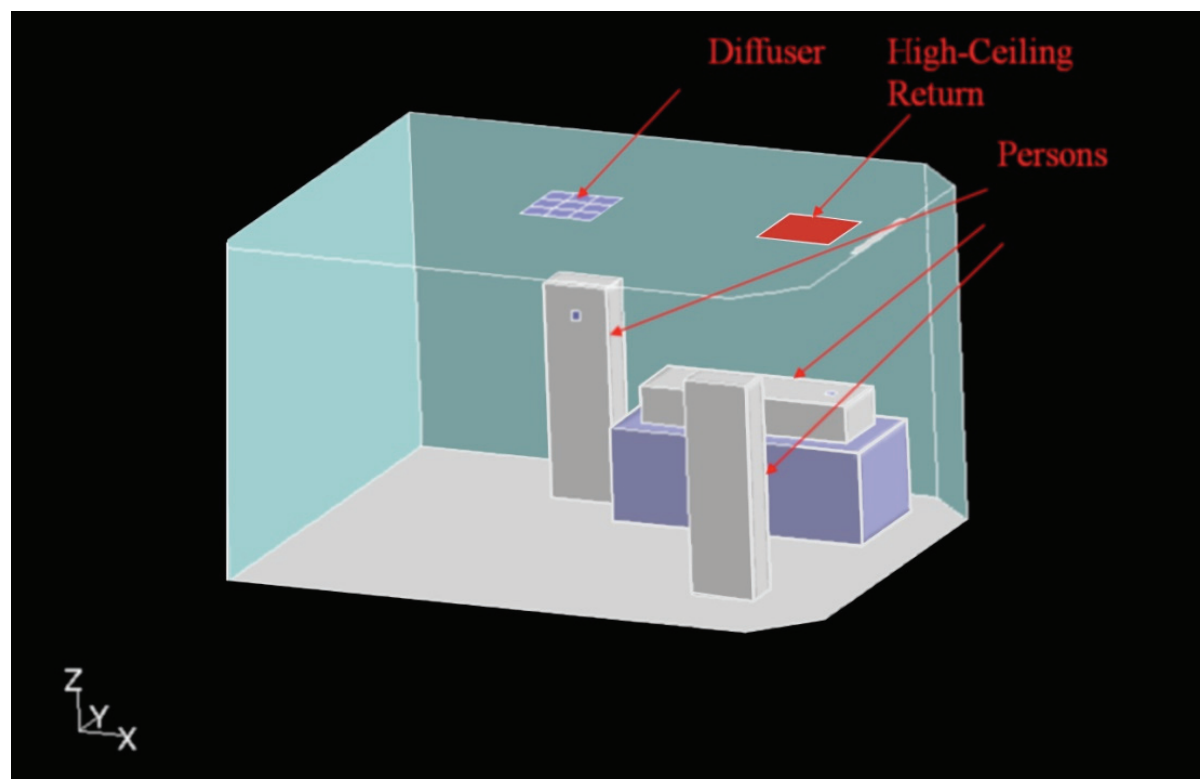

Figure 3. Model I of CFD analysis. Traditional diffuser, $0.61 \mathrm{~m} \times 0.61 \mathrm{~m}(24$ " $\times 24$ ") or $0.61 \mathrm{~m} \times 1.22 \mathrm{~m}\left(24 " \times 48^{\prime \prime}\right)$. Supply airflow: $12.18 \mathrm{~m}^{3} / \mathrm{min}(430 \mathrm{cfm})$ at $18.89^{\circ} \mathrm{C}\left(66^{\circ} \mathrm{F}\right)$. High ceiling return centered over the patient's head. Heat from human occupants: $92.26 \mathrm{~W} /$ person (315 Btu/(hr-person)). 


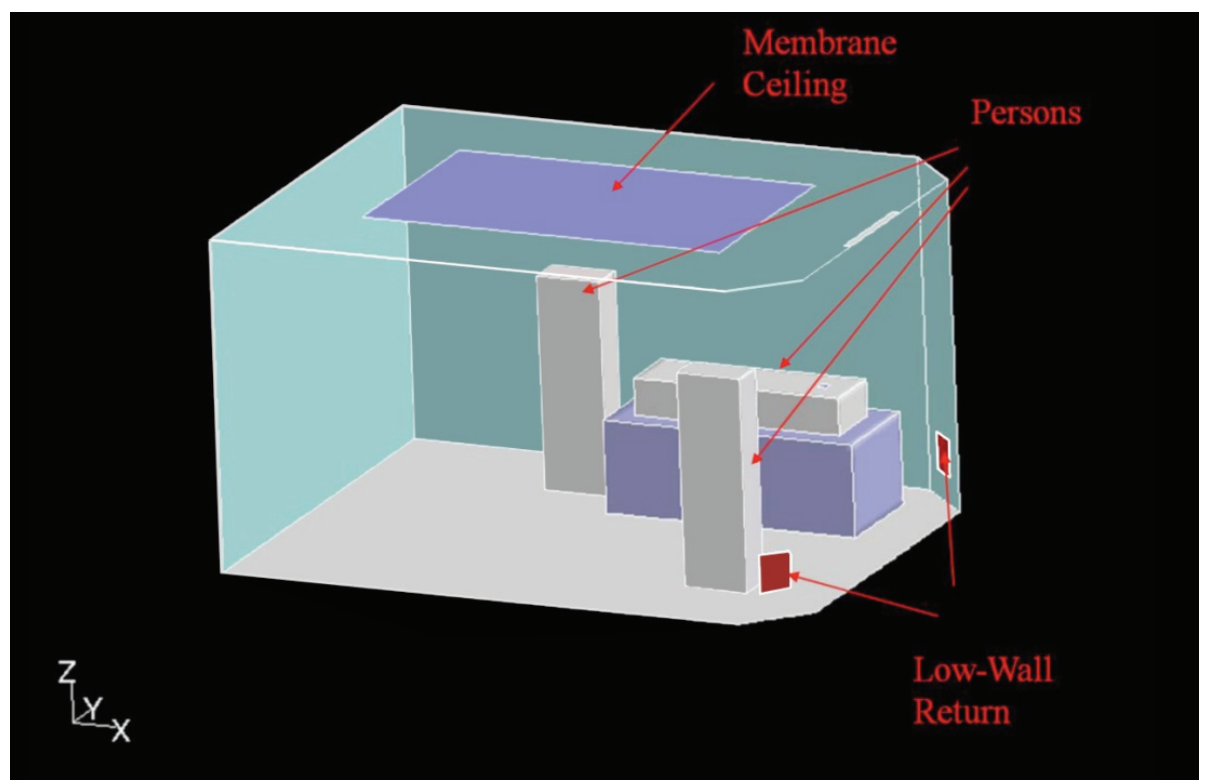

Figure 4. Model II of CFD analysis. Membrane diffuser ceiling. Supply airflow: 12.18 $\mathrm{m}^{3} / \mathrm{min}(430 \mathrm{cfm})$ at $18.89^{\circ} \mathrm{C}\left(66^{\circ} \mathrm{F}\right)$. Two corner low-wall return grilles. Heat from human occupants: $92.26 \mathrm{~W} /$ person (315 Btu/(hr-person)).

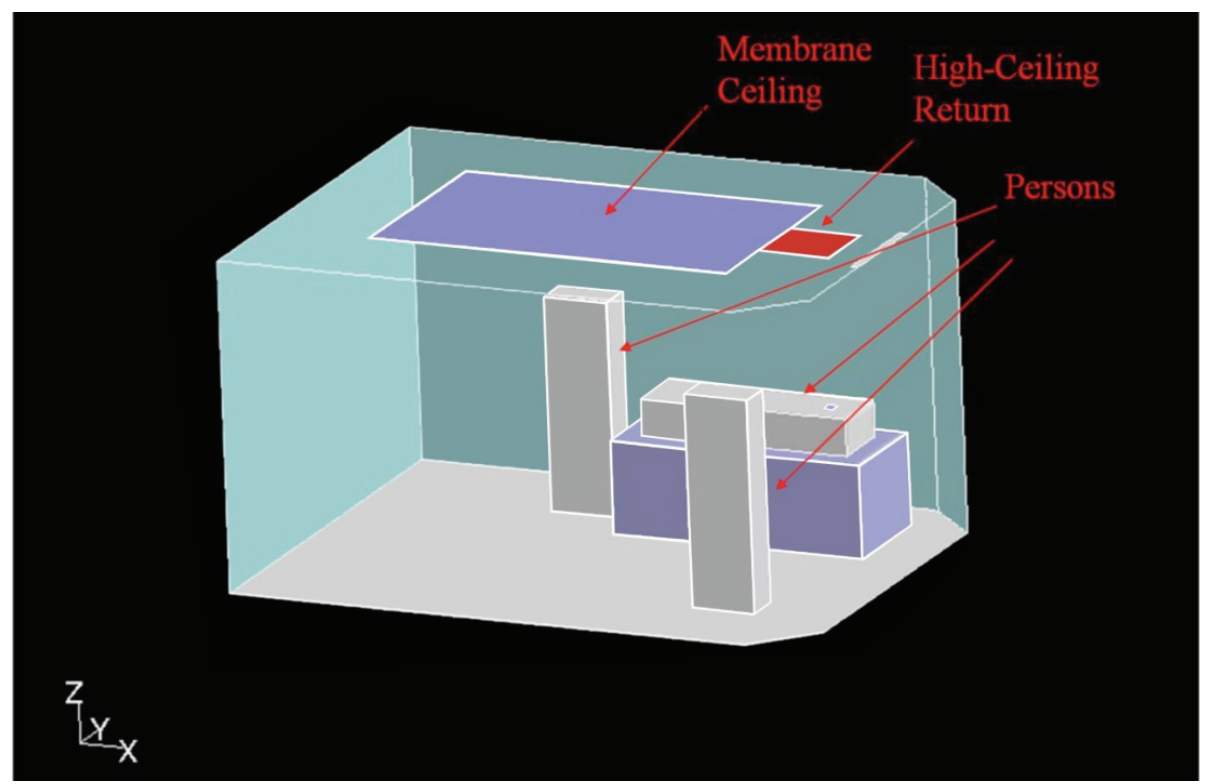

Figure 5. Model III CFD analysis. Membrane diffuser ceiling. Supply airflow: $12.18 \mathrm{~m}^{3} / \mathrm{min}(430 \mathrm{cfm})$ at $18.89^{\circ} \mathrm{C}\left(66^{\circ} \mathrm{F}\right)$. High ceiling return centered over patient head. Heat from human occupants: $92.26 \mathrm{~W} /$ person $(315$ Btu/(hr-person)). 


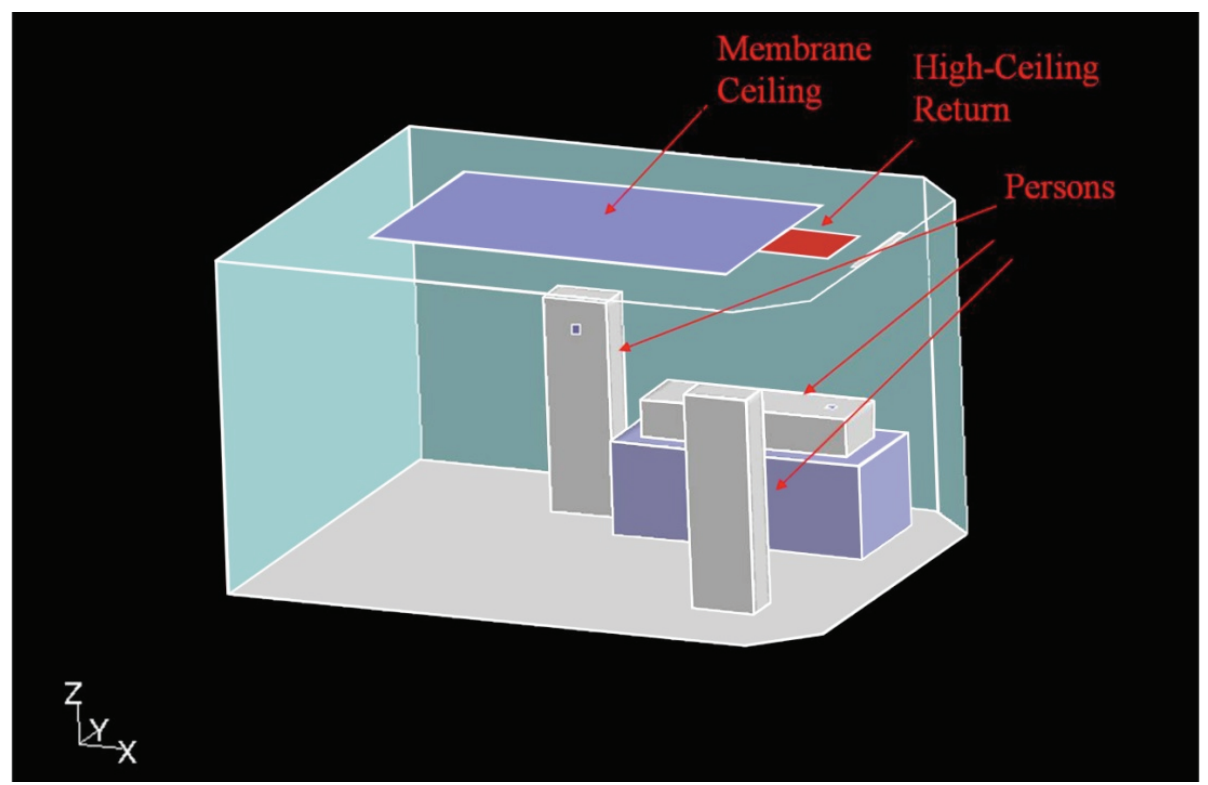

Figure 6. Model IV of CFD analysis. Membrane diffuser ceiling. Supply airflow: $12.18 \mathrm{~m}^{3} / \mathrm{min}(430 \mathrm{cfm})$ at $18.89^{\circ} \mathrm{C}\left(66^{\circ} \mathrm{F}\right)$. High ceiling return centered over the patient head. Heat from human occupants: $64.43 \mathrm{~W} /$ person $(220$ Btu/(hr-person)).

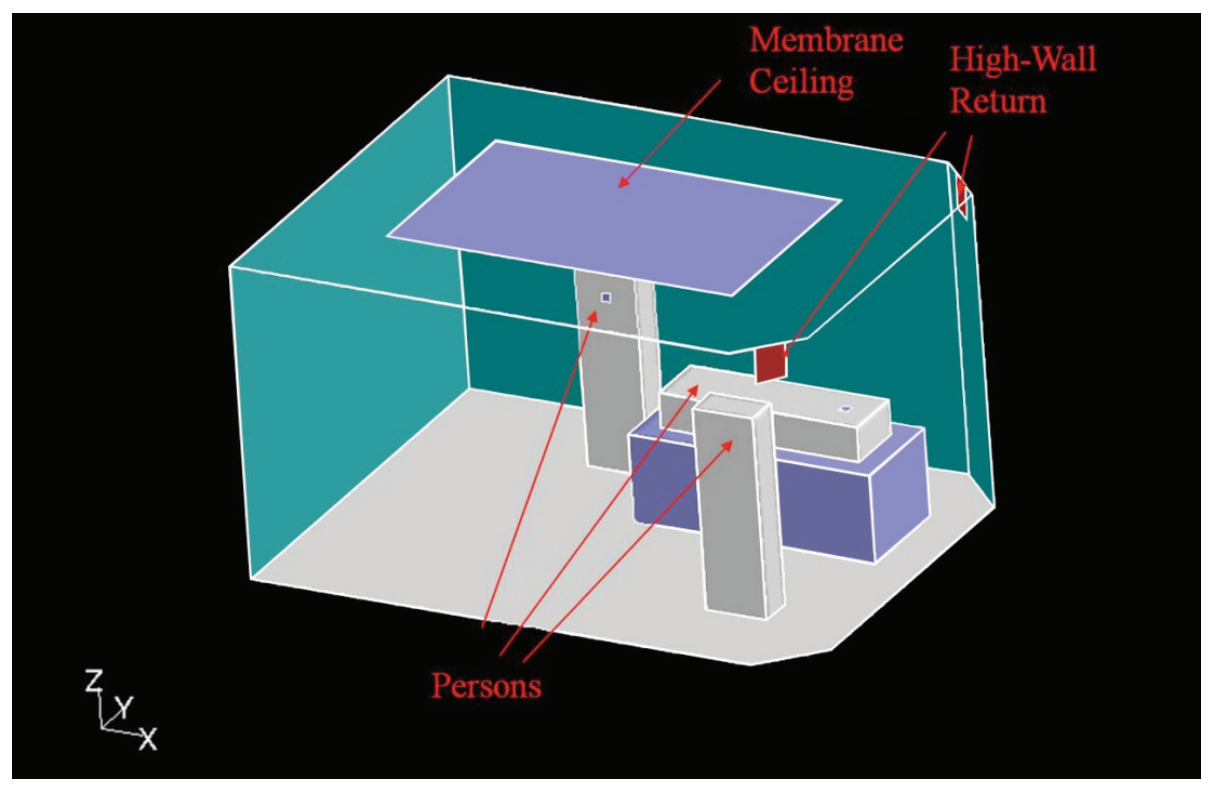

Figure 7. Model V of CFD analysis. Membrane diffuser ceiling. Supply airflow: $12.18 \mathrm{~m}^{3} / \mathrm{min}(430 \mathrm{cfm})$ at $18.89^{\circ} \mathrm{C}\left(66^{\circ} \mathrm{F}\right)$. Two corner high wall return grilles. Heat from human occupants: $92.26 \mathrm{~W} /$ person (315 Btu/(hr-person)). 


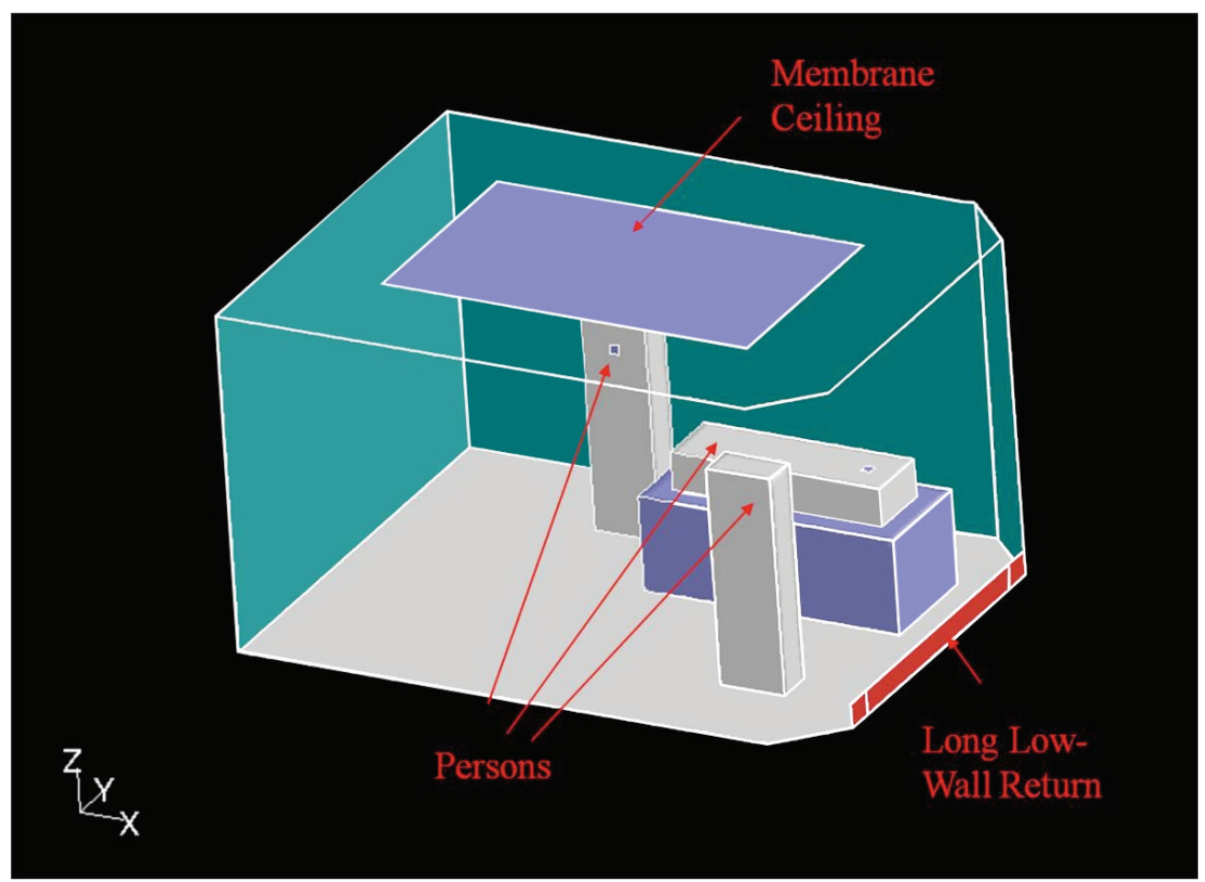

Figure 8. Model VI of CFD analysis. Membrane diffuser ceiling. Supply airflow: $12.18 \mathrm{~m}^{3} / \mathrm{min}(430 \mathrm{cfm})$ at $18.89^{\circ} \mathrm{C}\left(66^{\circ} \mathrm{F}\right)$. Long low-wall return grille. Heat from human occupants: $92.26 \mathrm{~W} /$ person (315 Btu/(hr-person)).

\section{RESULTS}

\subsection{Examination Room Mock-Up Performance Tests}

Testing the actual ceiling membrane diffuser system in the full size examination room mock-up provided airflow information utilizing a water based cold smoke introduced into the supply air stream at the membrane plenum and tracking the movement using professional video equipment.

Since membrane ceiling systems have never been applied and/or rigorously tested in a healthcare environment, special attention was focused on the performance of this novel ceiling air diffusion system in delivering air around the patient bed and health care provider locations. Utilizing the video recordings of the actual smoke tests, the actual airflow movement was correlated to that of CFD model. Besides considering the streamline and velocity of the air within the room, the CFD model assumed heat dissipation from the patient, healthcare provider, and visiting person at a rate from 64.43 to $92.26 \mathrm{~W}$ ( $220 \mathrm{BTU} / \mathrm{hr}$ to $315 \mathrm{BTU} / \mathrm{hr}$ ) depending on activity, and an expiratory air release from each person at $6000 \mathrm{ml} / \mathrm{min}(0.21 \mathrm{cfm})$. 
Table 1. Summary of the key input data for the six CFD models. Supply airflow: $12.18 \mathrm{~m}^{3} / \mathrm{min}(430 \mathrm{cfm})$ at $18.89^{\circ} \mathrm{C}\left(66^{\circ} \mathrm{F}\right)$ for all models.

\begin{tabular}{|c|c|c|c|}
\hline Model \# & $\begin{array}{l}\text { Ceiling } \\
\text { Type }\end{array}$ & Air Return Design & $\begin{array}{l}\text { Heat from } \\
\text { Occupants }\end{array}$ \\
\hline I & $\begin{array}{l}\text { Traditional } \\
\text { diffuser; } \\
0.61 \mathrm{~m} \times \\
0.61 \mathrm{~m} \\
\left(24 " \times 24^{\prime \prime}\right) \\
\text { or } 0.61 \mathrm{~m} \\
\times 1.22 \mathrm{~m} \\
\left(24 " \times 48^{\prime \prime}\right)\end{array}$ & $\begin{array}{l}\text { High ceiling return } \\
\text { centered over patient's } \\
\text { head }\end{array}$ & $\begin{array}{l}92.26 \mathrm{~W} / \text { person } \\
(315 \mathrm{Btu} /(\mathrm{hr}- \\
\text { person }))\end{array}$ \\
\hline II & $\begin{array}{l}\text { Membrane } \\
\text { diffuser }\end{array}$ & $\begin{array}{l}\text { Two corner low- wall } \\
\text { return grilles }\end{array}$ & $\begin{array}{l}92.26 \mathrm{~W} / \text { person } \\
(315 \mathrm{Btu} /(\mathrm{hr}- \\
\text { person }))\end{array}$ \\
\hline III & $\begin{array}{l}\text { Membrane } \\
\text { diffuser }\end{array}$ & $\begin{array}{l}\text { High ceiling return, } \\
\text { centered over patient } \\
\text { head }\end{array}$ & $\begin{array}{l}92.26 \mathrm{~W} / \text { person } \\
(315 \mathrm{Btu} /(\mathrm{hr}- \\
\text { person }))\end{array}$ \\
\hline IV & $\begin{array}{l}\text { Membrane } \\
\text { diffuser }\end{array}$ & $\begin{array}{l}\text { high ceiling return, over } \\
\text { patient }\end{array}$ & $\begin{array}{l}64.43 \mathrm{~W} / \text { person } \\
(220 \mathrm{Btu} /(\mathrm{hr}- \\
\text { person }))\end{array}$ \\
\hline $\mathrm{V}$ & $\begin{array}{l}\text { Membrane } \\
\text { diffuser }\end{array}$ & $\begin{array}{l}\text { Two opposite corner } \\
\text { high wall return grilles }\end{array}$ & $\begin{array}{l}92.26 \mathrm{~W} / \text { person } \\
(315 \mathrm{Btu} /(\mathrm{hr}- \\
\text { person }))\end{array}$ \\
\hline VI & $\begin{array}{l}\text { Membrane } \\
\text { diffuser }\end{array}$ & $\begin{array}{l}\text { Long low- wall return } \\
\text { grille }\end{array}$ & $\begin{array}{l}92.26 \mathrm{~W} / \text { person } \\
(315 \mathrm{Btu} /(\mathrm{hr}- \\
\text { person }))\end{array}$ \\
\hline
\end{tabular}

Utilizing the clean room test, multiple examination room mock-up tests were conducted. Stop image sequences from video were documented for four (4) different airflow tests. In the first two mock-up tests, the cold smoke was introduced at the room ceiling membrane diffuser located directly above the patient bed. With an air supply of $12.18 \mathrm{~m}^{3} / \mathrm{min}(430 \mathrm{cfm})$ and an exit face velocity of $4.57 \mathrm{~m} / \mathrm{min}$ (15 feet per minute), these tests showed the movement of air to demonstrate a slightly turbulent action in the area over the patient bed and toward the head wall low-level return grilles. Air 
movement toward the sides of the patient bed also indicated a slightly turbulent movement as the air changed direction from a downward movement to a horizontal movement. It was observed that with the higher exit velocity and shorter length of travel before the air had to make a transition to the head wall return grille, the air velocity was maintained higher, hence carrying more energy downward and was directed over the edge of the patient bed to the floor, at which point the air movement was recovered and directed to the low-level wall return grilles.

The other two mock-up tests were conducted with an expanded ceiling area membrane coverage to $5.57 \mathrm{~m}^{2}\left(60 \mathrm{ft}^{2}\right)$, while maintaining the $12.18 \mathrm{~m}^{3} / \mathrm{min}(430 \mathrm{cfm})$ supply air volume, located directly over the patient bed and extending $0.61 \mathrm{~m}$ ( 2 feet) beyond the foot of the patient bed. The test results for mock-up tests 3 and 4 indicated a lower discharge velocity of approximately $2.13 \mathrm{~m} / \mathrm{min}(7 \mathrm{fpm})$ providing for a more uniform or unidirectional airflow from the diffuser area over the patient bed and transitioning to the space just above the patient and with less turbulent air movement towards the head of the patient area. In the latter two tests, it was observed that the lower downward exit velocity from the membrane surface and a slightly longer air travel path facilitated a longer transition time from vertical movement to horizontal movement, thereby resulting in a more uniform transition without direct incident on the patient or patient bed. The air was able to travel in a more laminar pattern to the return grilles.

The information generated in the mock-up test was subsequently used in the CFD analyses. In essence, the smoke test was planned as a starting point to confirm air diffusion through the membrane panel system, discharge into the space and its deceleration activity, impact on system static pressure and light level performance in general. Using the smoke test result with a discharge air velocity of $15 \mathrm{fpm}$ and $7 \mathrm{fpm}$ (variable), the velocity of air through the membrane was used as a reference in the CFD analysis. The video results of the mock-up test were adopted as reference information. The smoke particle size, at 0.025 to 0.5 micron (not over 1.0 micron) was reviewed to confirm velocity of air, directional movement and entrainment capability.

\subsection{Results of CFD Analyses}

Figure 9 presents the contour of the mass fraction (mf) of the human expiratory air at $7.62 \mathrm{~cm}$ (3") above the patient for Model I through Model VI, respectively. The color bar on the left represents the level of the $\mathrm{mf}$. As shown in this figure, the mf of human expiration air is much higher in Model I, in which a traditional diffuser is used, than all the other five cases where the membrane ceiling was employed. The mf of human expiration air was lowest when returns were located high in the ceiling, as in Model III and Model IV. For comparison and illustration purposes, as shown in each model in Figure 9, the area where an arrow points had the level of $\mathrm{mf}$ that quantifies the above observations. In model I of Figure 9, mf value at the selected location was 0.03 , far higher than any of the other five models. The mf value of 0.001 representing the lowest level of all scenarios was obtained in both Model III and Model IV featuring ceiling membrane and high ceiling returns. 


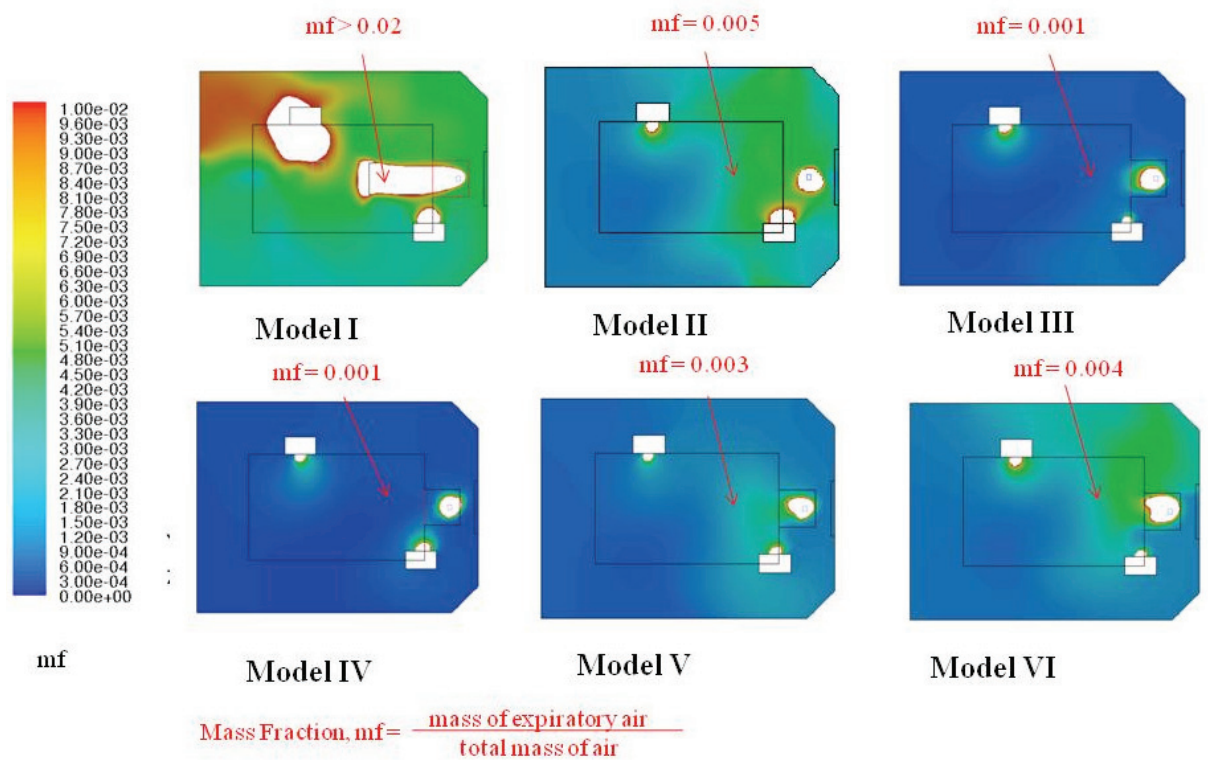

Figure 9. Contours of mass fraction of the human expiratory air at $7.62 \mathrm{~cm} \mathrm{(3")}$ above the patient for Models I through VI.

Figures 10 presents the airflow patterns inside the exam room for Models I through VI. In Model I, a large volume of mixing/turbulent air was observed throughout the entire room. This mixing/turbulent pattern occurred as the ceiling diffuser discharges the clean supply air at a high velocity and causes re-entrainment of the room air to mix with the supply air. Consequently, it caused more contaminants to be re-entrained and trapped in the space before exit. In contrast, the airflow patterns in Models II through Model VI, in which the membrane ceiling diffusion was used, were considerably more uniform and less turbulent, thereby providing a sweeping effect for efficiently washing away particulates within the space. Notably, airflow patterns in Model III and Model IV further facilitated the "sweeping process" as some contaminants lifted by buoyancy were directed to exhaust in one sweep through the high ceiling return, rather than being forced down into the lower wall returns for exit as in Models, II, V and VI. This "one sweep" mechanism may constitute a good explanation as to why Models III and IV had a higher ventilation performance than all other membrane ceiling models tested in this study.

Figure 11 shows the contour surfaces of $\mathrm{mf}=0.01$ for all models . Constant-mf contour surface is another way to evaluate the effectiveness of ventilation. Similar to findings in Figure 9, Figure 11 clearly shows that Model I provides a larger region of $\mathrm{mf}>0.01$ than all the other models. 
668 Airborne Contamination Control through Directed Airflow in the Exam Room: A Pilot Study Using a Membrane Diffuser
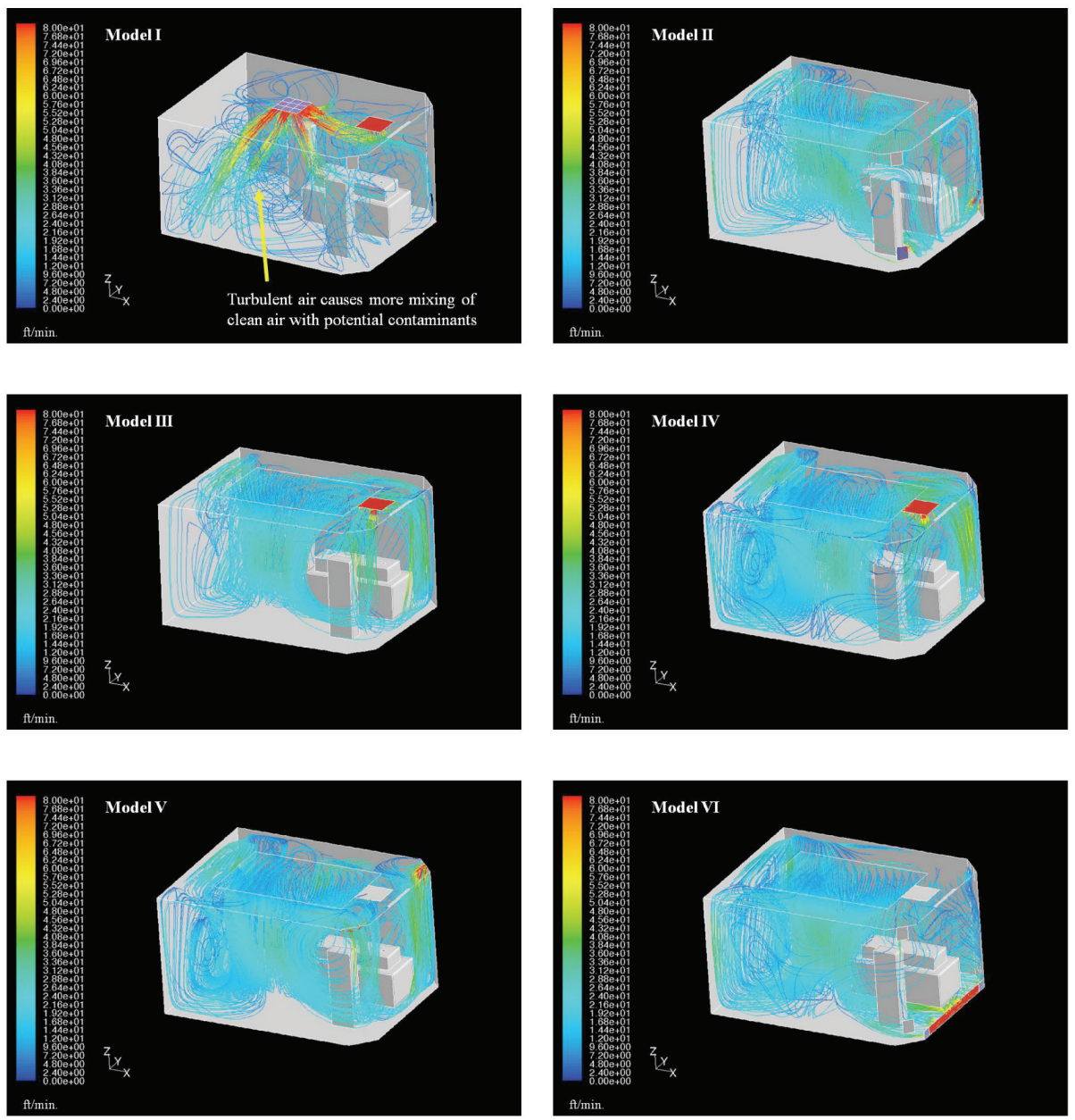

Figure 10. The airflow patterns inside the exam room for Models I through VI. 

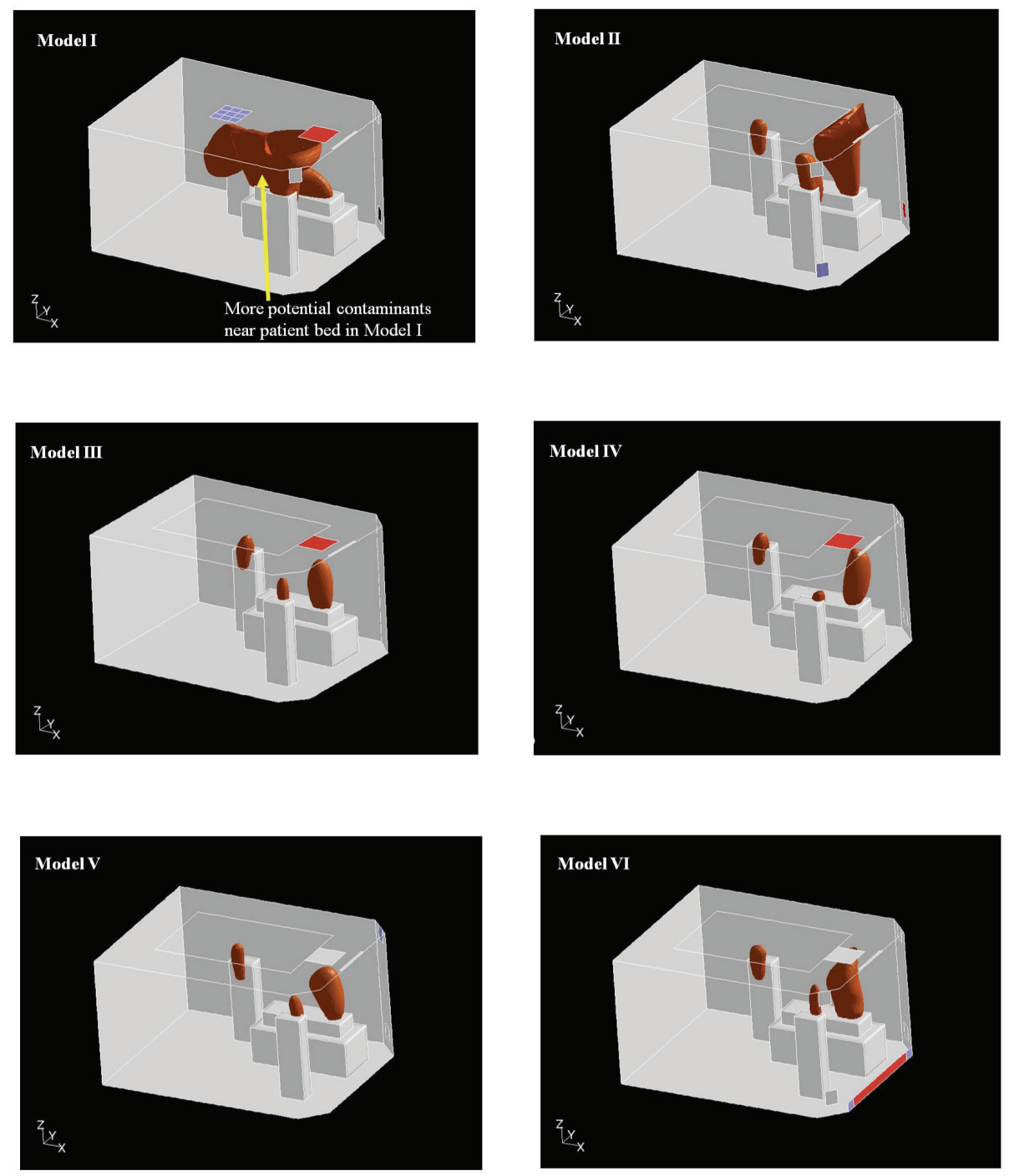

Figure 11. Contour surface of the mass fraction at $\mathrm{mf}=0.01$ for Models I through VI. 


\section{DISCUSSION}

The above CFD modeling results indicate that the membrane diffusion system, along with a high level ceiling return device(s), provides for an enhanced level of airborne contamination control within the exam room. Airflow in all cases presented using the membrane ceiling diffusion was found to provide a more desirable particulate movement than the traditional ceiling diffuser design.

The field mock up tests of the pressurized membrane system also confirm that the membrane creates a slight positive back-pressure which assists in diffusing air more evenly across the entire ceiling plane. This uniform velocity and unidirectional discharge of air effectively controls the movement of airborne particulate and reduces cross contamination typically caused by horizontal movement of air.

The CFD models support the membrane diffuser application in demonstrating reduced eddy currents that are typically held in place by the downdrafts induced by high velocity air movement and may be impacted by adjacent air devices or blocked off ceiling areas. The literature has already reported that particles are trapped in these eddy currents and not flushed out into the primary air stream. These eddy current areas serve as a reservoir which 'load and dump' particles into the room as reported in a BIOCON report [31] and by Hope and Milholl [26].

Airborne pathogens within droplets vary considerably in size, as do the sizes of droplets from coughing and speaking. Studies show that the mean diameter of droplet size from coughing is 13.5 micron and that from speaking is 16.0 micron [32], and there is a preponderance of particles less than 1.0 micron in size [33]. In general, droplets tend to vary widely in size from .5 to 100 micron. Pathogen sizes are smaller in comparison. In this study, the primary concern is droplet nuclei generated by coughing, talking, breathing, etc. These droplets tend to remain suspended in the air for minutes and thus are more affected by the direction and characteristics of airflow in the room [32]. The mean size of the smoke particles used in the mock up was 0.25 to 0.5 micron (not over 1.0 micron). The droplet size range examined would exclude the larger droplets originating from coughing and speaking. However, the kinetic energy embodied in the larger droplets as they are ejected from the mouth are typically beyond what could be practically targeted for dispersion control through ventilation system design. In other words, contamination through larger droplets aerosolized by coughing or talking and traversing between two persons in near proximity is not possible to control through typical ventilation flow rates. This type of cross contamination usually requires physical barriers such as surgical masks. However, many smaller droplets lose moisture, reduce in size and become droplet nuclei. This study finding is relevant to the dispersion patterns of small size droplet nuclei of less than 1.0 micron after losing moisture. These are the particles that tend to remain airborne for several minutes. That constituted the main focus of the study - to examine whether directional flow of particle droplets could be controlled in rooms similar to clinical settings.

This study was not evaluating what came through the air handling system. It was assumed that the supply air was purified by HEPA (High Efficiency Particulate Absorbing) filters and perhaps UV light. The objective was to figure out whether it is possible to help control the direction of the particles generated in the room by humans or by particles generated from surfaces inside the room. 
Traditional healthcare ventilation system design is well documented in the literature such as in the 2007 ASHRAE Handbook [34]. Ventilation design takes into account and addresses air movement from clean to less clean areas. Existing ventilation designs include constant-volume ventilation systems for critical-care areas, and variablevolume (VAV) systems for non-critical patient care areas with less energy consumption but requiring maintenance of minimum ventilation rates for special care areas.

Emergency rooms present the highest level of contamination potential within the hospital because of the soiled condition of arriving patients and/or due to the large numbers of accompanying persons. Membrane diffuser may provide advantages in terms of airborne particle control within the patient room over the traditional air distribution systems such as mixed air overhead distribution, thermal displacement ventilation, partial mixed systems or task/ambient air distribution designs.

In the case of mixed air distribution, high velocity air jets from the overhead air diffusers is mixed with room air. This is normally a turbulent action with migration of air to the return or exhaust grilles. Depending on the locations of the return grilles, it can provide high levels of cleanliness. In patient areas with VAV ventilation system, a part load condition can result in low outlet velocity thereby reducing room air mixing and compromising patient comfort. Similarly, cooling and heating with the same ceiling or high sidewall diffusers may impact the room thermal performance. In most cases, the mixing of air within the space is affected by patient beds, furniture and people within the space. Depending on air distribution techniques these appurtenances can provide a negative impact to air flow.

Among other ventilation options, in the case of floor or low side wall distribution systems, full thermal stratification systems are not normally encountered in the healthcare environment. For a partially mixed air distribution system, characteristics of both the mixed air system and the thermal stratified systems are incorporated. This includes high velocity mixing air zone and a low velocity stratified zone where room air is caused to move by thermal forces. This technique has application in some colder climates.

The membrane diffuser thus offers substantial promise over the other ventilation options. Despite limitations associated with computational simulation, this study was expected to build a foundation for further research leading to optimal design of ventilation systems for hospital rooms. Further smoke tests should be conducted based on the findings of the CFD analysis.

Accordingly, the objective of this study was not to investigate the clinical impact of the membrane ceiling technology on 'airborne infection rate'. The focus was on examining dispersion patterns of air particulates under different ventilation options. Understanding air particulate dispersion and flow is a pre-requisite to examining the impact of the membrane ceiling technology on airborne contamination. Thus, airborne contamination constitutes a logical area for future studies. Any space in a hospital where person-to-person airborne contamination is a possibility could benefit from controlled dispersion of air particulates. However, the effect of controlled dispersions achieved by membrane ceiling on reduced airborne contamination and infection needs to be examined in future phases of the study. 
Aerosolized particles can originate from various sources and vary greatly in size. The sources for aerosolized particulate matter can be ventilation systems, surfaces (both animate and inanimate), exhalation, spray bottles, compressed or force air sources and indeed others. The relevant sizes can vary from extremely small viral particles to very large droplets contained in cough material. The study can only relate to particle sizes similar to the size of the study smoke particles $(0.5$ micron $)$. It is recognized that particles of different size will behave differently in CFD modeling. However, our study was limited to the direction of the particles. Further studies will need to be done to establish the behavior of pathogenic particles in this model and to determine clinical relevance.

In this study, typical patient and staff attributes were used and not changed. For instance, the breathing rate value of $6000 \mathrm{ml} / \mathrm{min}(0.21 \mathrm{cfm})$ for a calm/healthy person was used in this study, but the value can be as high as $15000 \mathrm{ml} / \mathrm{min}(0.53 \mathrm{cfm})$ for patients suffering from asthma, congestive heart failure, COPD, hypothyroidism, etc. Variability in attributes of the patient and the staff should be included in future studies to examine their impact on air particulate dispersion.

\section{CONCLUSIONS}

Similar to previous studies, our analysis found that particle dispersion in rooms is very sensitive to diffuser type and configuration. The study demonstrated that a membrane diffuser that occupies approximately 20 to $30 \%$ of the ceiling surface of a contemporary sized exam room and placed directly over the patient at a location to the lower $2 / 3$ of the bed can provide a less turbulent and more desirable pattern of airflow. This was true with either a low return or a high return configuration. However, CFD analysis of the high return demonstrated a higher level of clean air in the room. Under typical hospital air supply velocity $(2.13 \mathrm{~m} / \mathrm{min} ; 7$ feet per minute $)$ the downdraft force of the air may not be sufficient to overcome the upward force of heat from bodies and breath. For this reason the high ceiling return configuration appears advantageous. Higher feet per minute flow velocities in the room can be used to overcome the upward force of heat generation from body and warm breath, but this is always done at an energy penalty. The airflow necessary to overcome the force of a cough at close range would create an uncomfortable environment in addition to consuming energy.

To take advantage of the natural upward movement of body heat and breath air some authors have proposed the use of displacement ventilation because the upward movement of all heat from the body is enhanced by the upward displacement of air affected by this ventilation strategy. Unfortunately, the very slow rate of displacement ventilation does not provide sufficient force to overcome the turbulence generated by the provider, patient and visitor movements in the room, nor does it have the power to "lift" aerosolized droplets. Such droplets are known to be a mode of infection transmission.

To summarize, a membrane diffuser directed airflow ventilation strategy occupying approximately 20 to $30 \%$ of the ceiling surface and placed over the lower $2 / 3$ 's of the patient bed in a contemporary sized examination room provides a less turbulent airflow pattern and less mixing of the air between the patient and others in the room.

Although there appears to be advantages in terms of less turbulence, better air 
cleanliness and more predictable airflow, further studies will be needed to ultimately determine if membrane ceiling diffuser - directed airflow ventilation - can actually translate into better outcomes in terms of cross contamination or infection transmission. The ultimate goal would be to lower cross contamination and infection rates without any significant increase in energy costs.

\section{ACKNOWLEDGEMENTS}

This study was carried out under a subcontract from Washington Hospital Center under the authority of the HHS grant 6 HFPEP070012-01-02. LUWA provided the Clean Room Technology fabrics for this study. The authors also acknowledge Patrick McLoad for video recording.

\section{REFERENCES}

[1] Centers for Disease Control, Morbidity and Mortality Weekly Report (MMWR) March 03, 2000, 49(08), 149-153.

[2] McKendrick, G. D., and Emond, R. T., Investigation of cross-infection in isolation wards of different design, Journal of Hygiene (Lond), 1976, 76(1), 23-31.

[3] Opal, S. M., Asp, A. A., Cannady, P. B., Jr., Morse, P. L., Burton, L. J., and Hammer, P. G., Efficacy of infection control measures during a nosocomial outbreak of disseminated aspergillosis associated with hospital construction, Journal of Infectious Diseases, 1986, 153(3), 634-637.

[4] Arlet, G., Gluckman, E., Gerber, F., Perol, Y., and Hirsch, A., Measurement of bacterial and fungal air counts in two bone marrow transplant units, Journal of Hospital Infection, 1989, 13(1), 63-69.

[5] Barnes, R. A., and Rogers, T. R., Control of an outbreak of nosocomial aspergillosis by laminar airflow isolation, Journal of Hospital Infection, 1989, 14(2), 89-94.

[6] Hopkins, C. C., Weber, D. J., and Rubin, R. H., Invasive aspergillus infection: possible non-ward common source within the hospital environment, Journal of Hospital Infection, 1989, 13(1), 19-25.

[7] Mehta, G., Aspergillus endocarditis after open heart surgery: An epidemiological investigation, Journal of Hospital Infection, 1990, 15(3), 245-253.

[8] Iwen, P. C., Davis, J. C., Reed, E. C., Winfield, B. A., and Hinrichs, S. H., Airborne fungal spore monitoring in a protective environment during hospital construction, and correlation with an outbreak of invasive aspergillosis. Infection Control and Hospital Epidemiology, 1994, 15(5), 303-306.

[9] Babb, J. R., Lynam, P., and Ayliffe, G. A., Risk of airborne transmission in an operating theatre containing four ultraclean air units, Journal of Hospital Infection, 1995, 31(3), 159- 168.

[10] Cotterill, S., Evans, R., and Fraise, A. P., An unusual source for an outbreak of methicillinresistant Staphylococcus aureus on an intensive therapy unit, Journal of Hospital Infection, 1996, 32(3), 207-216.

[11] Loo, V. G., Bertrand, C., Dixon, C., Vitye, D., DeSalis, B., McLean, A. P., et al., Control of construction associated nosocomial aspergillosis in an antiquated hematology unit, Infection Control and Hospital Epidemiology, 1996, 17(6), 360-364.

[12] Kumari, D. N., Haji, T. C., Keer, V., Hawkey, P. M., Duncanson, V., and Flower, E., Ventilation grilles as a potential source of methicillin-resistant Staphylococcus aureus causing an outbreak in an orthopaedic ward at a district general hospital, Journal of Hospital Infection, 1998, 39(2), 127-133.

[13] McDonald, L. C., Walker, M., Carson, L., Arduino, M., Aguero, S. M., Gomez, P., et al., Outbreak of Acinetobacter spp. bloodstream infections in a nursery associated with contaminated aerosols and air conditioners, Pediatric Infectious Disease Journal, 1998, 17(8), 716-722.

[14] Passweg, J. R., Rowlings, P. A., Atkinson, K. A., Barrett, A. J., Gale, R. P., Gratwohl, A., et al., Influence of protective isolation on outcome of allogeneic bone marrow transplantation for leukemia, Bone Marrow Transplant, 1998, 21(12), 1231-1238. 
[15] Friberg, B., Friberg, S., and Burman, L. G., Correlation between surface and air counts of particles carrying aerobic bacteria in operating rooms with turbulent ventilation: an experimental study, Journal of Hospital Infection, 1999, 42(1), 61- 68.

[16] Mahieu, L. M., De Dooy, J. J., Van Laer, F. A., Jansens, H., and Ieven, M. M., A prospective study on factors influencing aspergillus spore load in the air during renovation works in a neonatal intensive care unit, Journal of Hospital Infection, 2000, 45(3), 191-197.

[17] Oren, I., Haddad, N., Finkelstein, R., and Rowe, J. M., Invasive pulmonary aspergillosis in neutropenic patients during hospital construction: Before and after chemoprophylaxis and institution of HEPA filters, American Journal of Hematology, 2001, 66(4), 257-262.

[18] Panagopoulou, P., Filioti, J., Petrikkos, G., Giakouppi, P., Anatoliotaki, M., Farmaki, E., et al., Environmental surveillance of filamentous fungi in three tertiary care hospitals in Greece, Journal of Hospital Infection, 2002, 52(3), 185-191.

[19] Lutz, B. D. J., Rinaldi, J., Wickes, M. G., Huycke, B. L., and Mark M., Outbreak of invasive Aspergillus infection in surgical patients, associated with a contaminated air handling system, Clinical Infectious Diseases, 2003, 37(6), 786- 793.

[20] Moran, G., McCabe, F., Morgan, M., and Talan, D., Delayed Recognition and Infection Control for Tuberculosis Patients in the Emergency Department, Annals of Emergency Medicine, 1995, 26(3), 290-295.

[21] Monmany J., Rabella, N., Margall, N., Domingo, P., Gich, I., and Vázquez, G., Unmasking Influenza Virus Infection in Patients Attended to in the Emergency Department, Infection, 2004, 32(2), 89-97.

[22] Li, L., and Gu, J., SARS Infection Among Health Care Workers in Beijing, China, JAMA, 2003, 290(20), 2662-2663.

[23] Huddy, J., How pandemic risk influences emergency department design, Healthcare Design, October 2009, http://www.healthcaredesignmagazine.com/ME2/dirmod.asp?sid=\&nm=\&type=Publishing \&mod=Pu blications\%3A\%3AArticle \&mid=8F3A7027421841978F18BE895F87F791\&tier=4\&id=8D2821C92 F6C45A49F0FDF9ACA618E67

[24] Moll, C. J., and Anderson, W. C., Vertical Laminar-Flow Clean Room of Flexible Design, 1972, US Patient No. 3,638,404, http://www.freepatentsonline.com/3638404.html.

[25] Lavedrine, I., Thomas, P., Tharp J., et al., Innovative Design Solutions for Burn Intensive Care Units, Proceedings of the $9^{\text {th }}$ International IBPSA Conference, Montreal, Canada, 2005, August.

[26] Hope, D., and Milholl, D., A three-dimensional ultrasonic anemometer to measure the performance of clean zone air delivery systems, Journal of the IES, 1993, 36(6), 32-40.

[27] ASHRAE, Space Air Diffusion, ASHRAE Handbook of Fundamentals, chapter 20, 2009, www. Ashrae.org

[28] AIA Academy of Architecture for Health, Guidelines for Design and Construction of Hospitals and Healthcare Facilities, The American Institute of Architects, Washington, DC, 2006.

[29] JACHO, Planning, Design, and Construction of Health Care Facilities, Second Edition, Joint Commission Resources, Oak Brook, IL, 2009.

[30] ASHRAE, 200 Special Project 91, HVAC Design Manual for Hospitals and Clinics, ASHRAE, Atlanta, GA, 2003.

[31] Milholl, D.C., Membrane Diffuser Evaluation, LUWA USA, BIOCON, 1988.

[32] Chao, C., Wan, M.P., Morawska, L., Johnson, G.R., Ristovski, Z., Hargreaves, M., Mengersen, K.L., Steve, C., Li, Y., Xie, X., and Katoshevski, D., Characterization of expiration air jets and droplet size distributions immediately at the mouth opening, Journal of Aerosol Science, 2009, 40(2), 122-133.

[33] Papineni, R.S. and Rosenthal, F.S., The size distribution of droplets in the exhaled breath of healthy human subjects, Journal of Aerosol Medicine, 1997, 10(2), 105-116. Papineni, R.S. and Rosenthal, F.S., The size distribution of droplets in the exhaled breath of healthy human subjects, Journal of Aerosol Medicine, 1997, 10(2), 105-116.

[34] ASHRAE, ASHRAE Handbook - HVAC Applications, chapter 7, 2007, www. Ashrae.org 


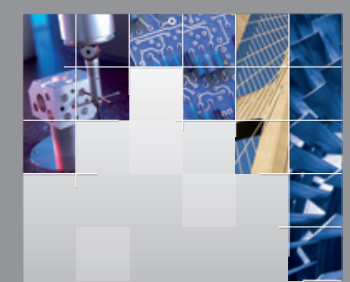

\section{Enfincering}
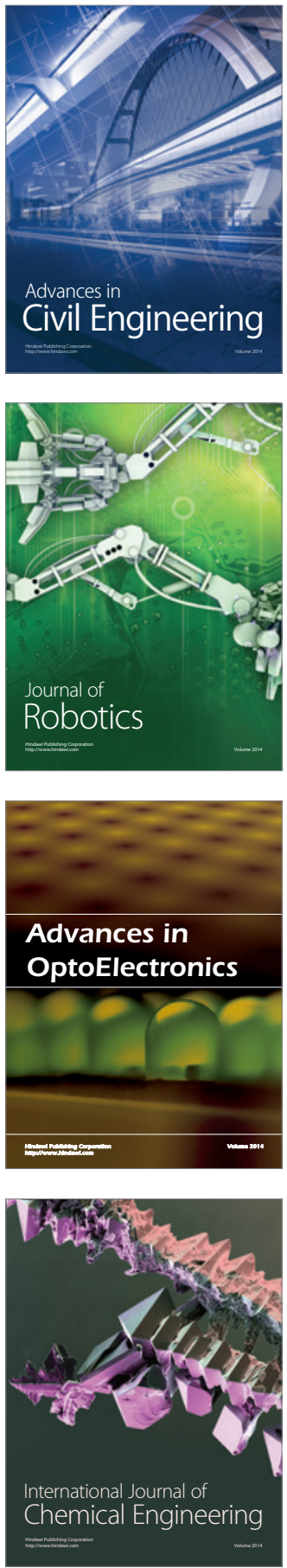

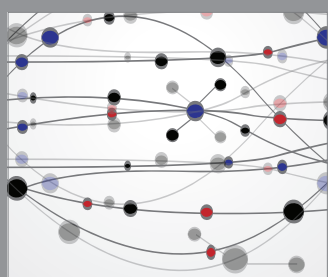

The Scientific World Journal

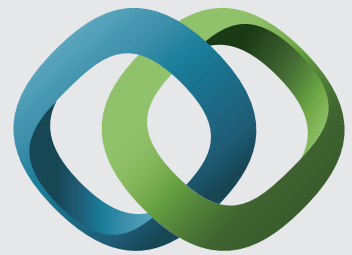

\section{Hindawi}

Submit your manuscripts at

http://www.hindawi.com
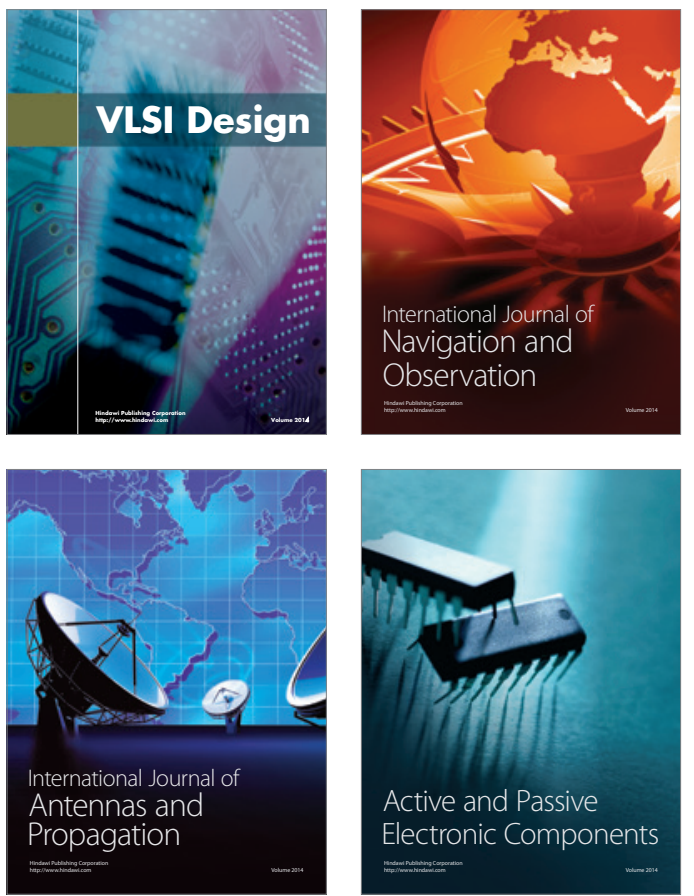
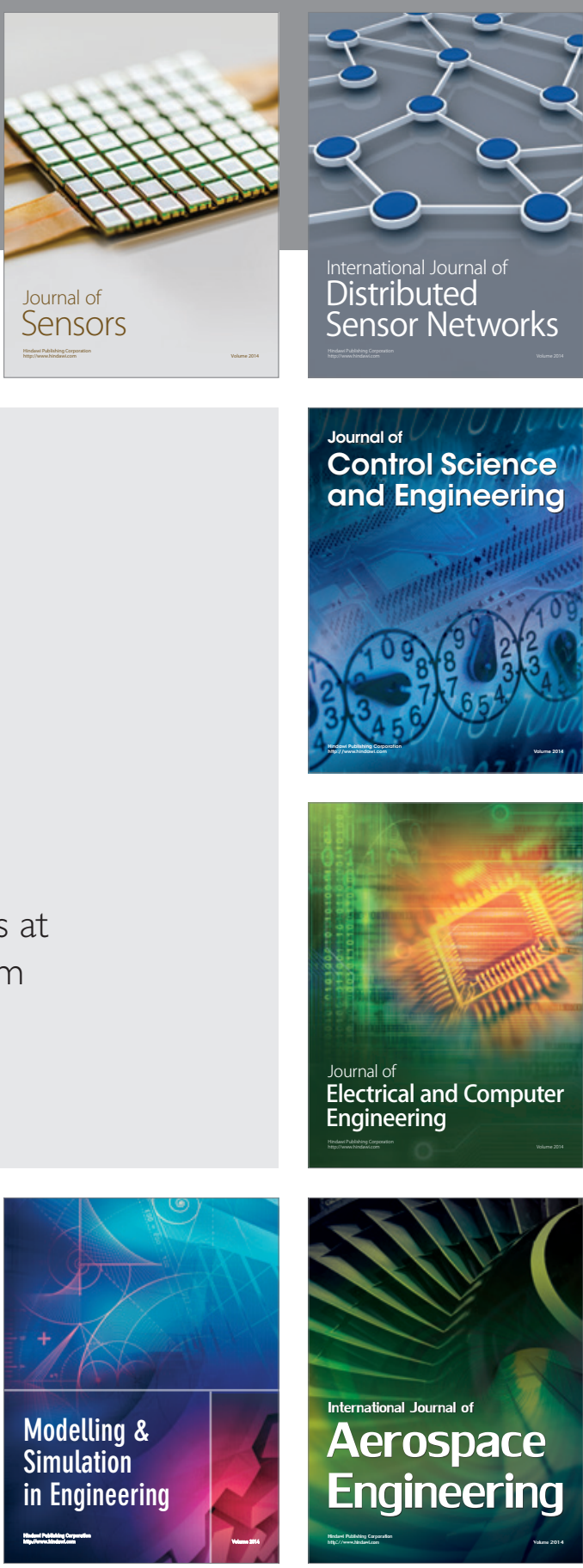

International Journal of

Distributed

Sensor Networks

Journal of

Control Science

and Engineering
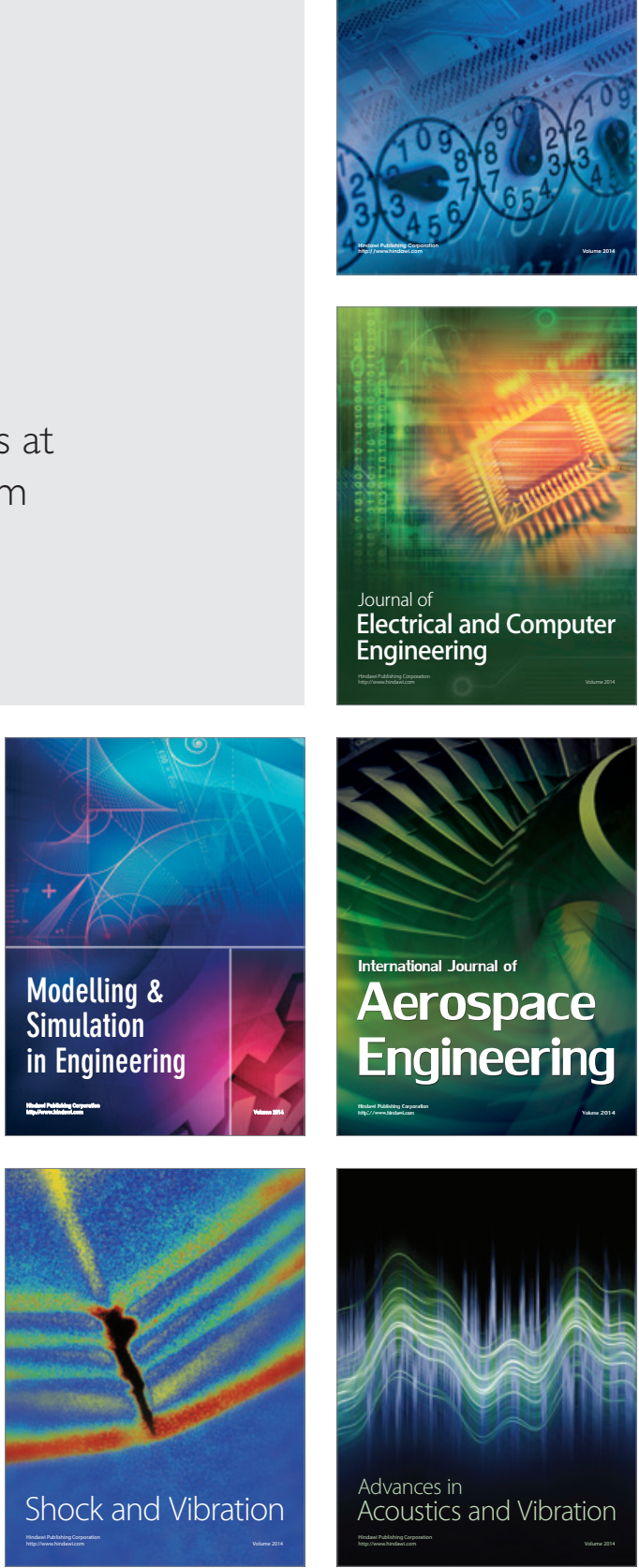